\title{
Features of designing tutors for education master's training
}

\author{
L.V. Goryunova ${ }^{1 *}$, and E.V. Polyakova ${ }^{2}$ \\ ${ }^{1}$ Southern Federal University, Rostov-on-Don, Russia \\ ${ }^{2}$ Southern Federal University, Rostov-on-Don, Russia
}

\begin{abstract}
The article discusses and details the features of designing the contents of the educational program of tutors' master's training, implementing the accompaniment of students in the conditions of individualization of the educational process. Separately, factors affecting the content of the training curriculum at the university are considered. In addition, a significant segment of the study is devoted to the identification of topical areas which are "requesting" tutorials for students to implement their individual educational routes. The role of the modular approach in the design of the training curriculum for tutors in the master's degree for the education system has been revealed and updated. A special place in the structure of the study is occupied by the results of the development of professional competences of a tutor, based on professional functions formulated by employers in the professional standard, as well as the designed modular content of the training curriculum for the education system. This modular training design will ensure the formation of a set of professional competencies that ensure the tutor's readiness to implement design, methodical and accompanying activities in the space of modern education, including remote.
\end{abstract}

\section{A problem statement}

Features of the development of modern society determine the functioning of the education system in the direction of its individualization. That allows to ensure the formation and development of the personality of each person, means of education in the range of his individual resources. At the same time, there is a constant search for effective innovative forms of educational activity, as well as the creation of educational spaces that contribute to the maximum disclosure of the makings and abilities of each student. Individualization is a modern trend of education all over the world because it allows for maximum manifestation of human activity [1]. It is in the context of individualization of education that the student can exercise his right to form the content and the individual line of his own education, adequate to his interests, abilities, requests, intentions [2]. Space, designed in the context of individualization of education, provides the implementation of a significant number of

\footnotetext{
* Corresponding author: prof-ped.gpa@mail.ru
} 
different educational routes, which changes the position of the learner in relation to their own development. All this determines the organization of the educational process in which the student is given the opportunity to choose the direction of their individual development and how to implement it. At the same time, to implement individualization in education, it is necessary to introduce the position of a tutor [3], which becomes for the learner the organizer of the space of educational opportunities and accompanying it in the process of determining and choosing an individual educational route. Or the teacher begins to perform the functions of a tutor. In both cases, the professionalism of the new quality is required from the teachers [4].

Thus, there was a problem related to the need for systemic training of tutors for the educational sphere. Implementation of educational programs for the training of tutors in higher education will allow to form a human resource that will provide educational organizations with specialists implementing tutoring support of individual educational routes of students of different categories, as well as intensify the design and activity component of their training, including in remote access. On this basis, it would be fair to designate the above thesis as a key problem of the study.

\subsection{The objective of the work}

The above problem is reflected in the works of domestic and foreign authors. But, despite this, the problem of training tutors in accordance with the modern requirements of employers in the higher education system is not fully solved. This allowed us to conduct our own research to present new results based on theoretical material that could complement such a section of pedagogical science as the theory and methodology of vocational education. The theoretical basis of the study is the works of scientists such as L.V. Bayborodova, S.V. Dudchik, T.M. Kovaleva, V.V. Korshunova, M.P. Krivun, E.I. Kuznetsova, L.N. Ruliene, A.A. Terov, E.V. Khachatryan, L.E. Molerio Sáez, J.A. Torres Pérez, C.A. Sánchez-Núñez, S. Ramírez Fernández, A. García Guzmán and others. The analysis of the work of these researchers was an important stage in the process of updating the problem of our research, its comprehension and solution.

\section{Results of the research}

The questions of studying the tutor's activities and the process of their training gained their most popularity in Russia at the beginning of the 21 st century, when there was a change in the direction of formation and development of the individual, able to live and act in an everchanging environment. It was during this period that the first time was mentioned the need to implement the support of students in the national education, so there was a question about the introduction of tutor's position and, accordingly, the training of tutors [5-11]. In Russia, in May 2008, the qualification groups of general, higher, and additional vocational education positions were approved, including the position of a tutor. And in 2009, the Southern Federal University for the first time in the South of Russia gathered specialists in the field of tutor escorts and conducted short-term refresher courses under the program "Tutor in the education system" [12].

Analysis of the content of the program and its demand, allowed to highlight several key topical areas of tutor training for education, which were later presented in the educational landscape of the university as a master's program "Tutoring in education." It should be noted that the education of people with disabilities has become more actively addressed during this period, focusing on everyone in the individual context of solving the problem. Accompanying people with educational disabilities is the first area of tutor's activity. This 
provoked the need to include in the content of master's training tutors a section related to tutoring support of students with disabilities, as well as the opening and implementation in 2011 of programs of professional development "Health-saving technologies in tutoring activities of educational institutions" and "Tutor escort of children with disabilities in remote education." About 900 people, education workers, took refresher courses in these programs. Analysis of the demand for these programs allows to highlight the second sphere of tutor's activity - it is tutoring students in the conditions of distance education. This area of tutor's activity became especially relevant in 2020, when the education system of the world moved to a remote format of functioning. That could not but affect the content of the master's program of tutor training.

In 2015, the Southern Federal University launched the Southern Federal District Educational Cluster as one of the most effective forms of partnership between the university and general education organizations, working together to improve the work with children with outstanding abilities, and in the direction of training future teaching staff [13]. The experience and development gained during the implementation of this project allowed the opening of the University Specialized Training and Scientific Center of the Southern Federal District in the spring of 2020. The main task of the center was to create the conditions for the formation of research competencies and personal development of talented students who showed outstanding abilities in study, science, scientific and technical creativity. To solve the problem, the educational process in the center is built based on individualization, which in turn determined the need to accompany students with tutorials. Consequently, the accompaniment and work with talented children and young people who have shown outstanding abilities is a third area of tutor's activity, which in turn also affects the selection of the content of tutors' master's training at the university. In 2021, the Talent and Success Foundation began the process of selecting tutors, with the aim of organizing pedagogical support for senior school-age students and students in their implementation of individual educational routes and projects. This fact allows us to conclude that the project activity of students at all levels of education requires the maintenance of the Tutor.

From 2019, Southern Federal University in conjunction with NTI University 2035 (https://intensive.2035.university/autumn2019) conducts SfeduNet Design and Education Intense courses, which is a format of project-oriented education, which counts both the teamwork of students on the project and education on individual educational routes, when the participants accompanied by tutors, form their educational needs and design individual programs, providing the satisfaction of these needs [14].

The Tutor in project-oriented education accompanies the learner in the conditions of "active learning" and creates a space in which the conscious approach of the learner to his educational route becomes possible. So, the accompaniment of the student's project activity is the fourth area of tutor's activity in education. Thus, the content of the master's program of tutor training for the education system since 2010 has undergone several transformations related to such factors as the actualization of four areas of tutor's professional activities.

Another significant factor that influenced the structure and content of the tutor's educational training program was the 2017 Approved Professional Standard "Specialist in Education", which spells out the main work functions of a specialist in the position of a tutor. The third factor that has influenced the process of improving the program of tutor training at the master's level is the inclusion of the profession "Tutor" in the Atlas of New Professions [15]. The Atlas of New Professions states that a tutor working in education should have such super-professional skills as "systemic thinking, client orientation, interindustry communication, project management, and work with people".

Thus, in 2020, the educational program of the master's degree "Tutoring in Education" was designed. The aim of the master's program is to train highly qualified teachers in the field of tutor support for the implementation of students of different categories of individual 
educational routes, projects at all levels of the system of national education, which will meet the needs of the country and the region in tutors capable of working in the modern education system. As part of the master's program, graduates are ready to implement such activities as pedagogical, design, methodical and support activities. After the implementation of the curriculum of the first year of study, half of which took place in remote access due to the pandemic of coronavirus, we conducted a survey of students. Thirty-two students studying in the Education Program took part in the survey. The analysis of the results of the survey formed the basis of a number of changes in the structure of the curriculum, which will be implemented to recruit students for this program in 2021. When asked about the difficulties students faced during the course of the Tutor practice, $82 \%$ of students said that it is difficult for them to carry out the tutor accompaniment in the conditions of distance learning. Such a high percentage of students experiencing these difficulties is due to the fact that the content of the programs of previous years of study included review subjects on the organization of tutor activities using information technology, which will ensure that students are prepared for the implementation of tutoring students in a fully remote format. In this regard, it was decided to include in the list of professional competencies, competence related to the development of the ability to implement professional activities in the digital educational environment (distant), as well as to include in the structure of the curriculum a module that allows to form this competence.

The set of professional competencies of the graduate of the educational program "Tutoring in education" which is formed during the development of the content of the program were developed by us on the basis of labor functions (pedagogical support of the implementation of individual educational routes, projects; design of the educational environment, where the students implemented individual educational routes, projects; organizational and methodical support for the implementation of individual educational routes, projects).

Professional Competence (PC-1): capable of professional activities in a digital information and education environment. Indicators of achievement of professional competence are:

- a student has the skills to carry out professional activities in distance learning systems (PC-1.1);

- $\quad$ organizes the student's support taking into account the opportunities of the digital educational environment of the educational organization and the open information and educational space (PC-1.2).

Professional Competence (PC-2): a student can provide pedagogical support to participants in the educational process, including those with special educational needs, as well as to organize their own professional and personal development. Indicators of achievement of professional competence are:

- familiar with the basic technologies of pedagogical support of participants in the educational process, including persons with special educational needs (PC-2.1);

- applies in organizations that carry out educational activities technology of pedagogical support of participants in the educational process, including persons with special educational needs (PC-2.2);

- is able to organize their own professional-personal development of the PC (PC2.3).

Pprofessional competence (PC-3): can develop scientific, organizational, and methodical support for the implementation of students' individual educational routes, curricula, projects. Indicators of professional competence are:

- a student is well orientated in modern methodical means of development and implementation of individual educational routes, curricula, projects taking into account their special educational needs (PC-3.1); 
- has the skills to develop methodical support for the implementation of students, individual educational routes, curricula, projects taking into account the trends and requirements of modern legislation (PC-3.2).

Professional competence (PC-4): a student can design and organize an educational environment for the implementation of individual educational routes, curricula, projects. Indicators of professional competence are:

- a student has an understanding of the technologies of designing an open, variable educational environment in educational organizations (PC-4.1);

- designs and organizes an educational environment for students to implement individual educational routes, curricula, projects (PC-4.2).

The design of the training content modules [16] was based on the above-mentioned professional competencies [17].

A modular approach was put into the curriculum for the training of students under the Education Program. Modular design of training plans ensures the adaptability of educational programs to the changing tasks of employers [18]. A modular approach to the design of educational programs, allows you to design a curriculum focused on competence [19]. Using a modular approach in curriculum design improves the effectiveness of the learning evaluation process [20]. Therefore, each module of the curriculum ends with a competent exam, allowing to assess the level of competence of students in the development of the content of the module.

The modular curriculum consists of theoretical (theoretical training in an educational institution) and practical (practical training in the organization of a potential employer) parts, i.e., has a dual structure.

During the first year of study, the student masters:

- $\quad$ the module with contemporary problems in science and education;

- the module of the general basics of tutoring activities (normative-legal basis of tutor's activities in all types of educational organizations; the theoretical foundations of tutoring activities);

- the module of the organization of the tutor accompaniment (technology of the tutor escort of students; the system of tutor support in organizations that carry out educational activities on the basis of the project approach);

- the training module of the student's tutor support (methodical support for individual educational routes of students, projects; methodical provision of tutor's activities in education);

- $\quad$ module of foreign language communicative competence.

During the second year of study, the student masters:

- the design module in tutor activities (designing the educational environment of the implementation of the individual educational route, the project; designing tutoring students based on their individual characteristics, abilities);

- the module of the tutor accompaniment in inclusive education;

- the tutor escort module in distance education (the organization of the tutor escort of students in distance education; the method of tutor accompaniment in distance education).

The model of practical training of students under the master's program "Tutorship in education" includes four consecutive stages: the stage of model practice (training practice, research work); the stage of practice-testing (educational practice); the stage of project practice (educational tutorial practice); the stage of practice-immersion (pre-practice, research). 


\section{Conclusions}

The results of this study have led to several conclusions about the design of the educational tutor training program for education. First, the introduction of the student's tutor service at all levels of the modern education system is an inalienable condition for the implementation of the principle of individualization of the educational process.

Secondly, a specialist to implement the top-level accompaniment of different categories of students in educational organizations of all types and types must be specially prepared in universities.

Thirdly, the content of tutor training for the education system should be structured in accordance with the requirements of the spheres "requesting" tutor support, as well as considering the work functions presented in the professional standard by employers.

Based on these basic provisions, a modular training plan for tutors in master's degree was developed, which was successfully implemented in 2019-2020 and improved to reflect the new conditions of education. It is important to understand that the implementation of such a program of tutor training will allow to provide the education system with qualified personnel who carry out an effective process of tutoring of the individual educational route implementation, the project.

\section{References}

1. M.B. Aliyeva, K.A. Akhmedpashayeva, E.A. Magomedova, The successes of modern science, 7, 111-114 (2017)

2. T.M. Kovaleva, T.V. Jakubowska, The Man.RU, 12, 85-94 (2017)

3. T.M. Kovaleva, Education issues, 2, 163-181 (2011)

4. E.V. Khachatryan, T.M. Kovaleva, Business. Education. Law, 3, 378-386 (2018)

5. L.V. Bayborodova, M.P. Krivun, Training of tutors for education (2020)

6. S.W. Dudchik, T.M. Kovaleva, Business. Education. Law, 3, 369-375 (2018)

7. V.V. Korshunova, Journal of Siberian Federal University. Humanities and Social Sciences, 2, 164-174 (2019)

8. E.I. Kuznetsova, A.A. Terov, Business. Education. Law, 4, 423-432 (2018)

9. L.N. Ruliene, Scientist's notes ISGZ, 1, 417-421 (2018)

10. L.E. Molerio Sáez, J.A. Torres Pérez, Revista Educación Médica del Centro, 5, 103-115 (2013)

11. C.A. Sánchez-Núñez, S. Ramírez Fernández, A. García Guzmán, Revista de Docencia Universitaria, 9, 119 (2011)

12. L.V. Goryunova, News of higher education institutions. North Caucasus region. Social sciences, 6(154), 149 (2009)

13. O.V. Galustyan, V.A. Kirik, N. Mazáčová, International Journal of Emerging Technologies in Learning, 17, 153-161 (2019)

14. The tutor maintenance of the project activities of students: theoretic and methodological foundations and practice of implementation: collective monograph (2020)

15. Atlas of new professions 3.0. (2020)

16. V. Zabotkina, O. Sudakova, M. Korovkina, Tuning Journal for Higher Education, 7, 67-92 (2019)

17. L.V. Krasheninnikova, RMAT Herald, 2, 91-97 (2018) 
18. P.S. Makrygiannis, A. Paradisi, T. Tsapelas, E.C. Papakitsos \& D.Piromalis, European Journal of Engineering Research and Science, 17-21 (2020)

19. M. Sürmeli, The European Conference on Technology in the Classroom (2016)

20.Z.S. Sadia Sadiq, Effectiveness of Modular Approach in Teaching at University Level, Journal of Education and Practice, 5, 103-110 (2014) 